\title{
Strategic Innovation in Tourism. A Conceptual and Review Approach
}

\author{
Almaz Sandybayev \\ Faculty Member, Business Administration Department, Abu Dhabi Men's College, Higher Colleges \\ of Technology, UAE
}

\begin{abstract}
Tourism is one of the fastest growing and promising areas of management with a high economic and social importance for the economy of many countries. Current conditions of tough competition in the tourist market, economic and political instability in many regions, the fast-growing needs and demands of tourists are proposing a new challenge of transition to an innovative path of tourism development industry.

The article discusses the issues of strategic innovative activity in the sphere of tourism and presents the main areas of innovation in the tourism sector, as well as factors affecting the innovative development of tourism. According to the author, the number of factors underlying features of innovative activity in the sphere of tourism includes specific properties of the tourism product, producers and consumers of tourism services. The purpose of the article is to describe the principles and basic requirements for the management system of innovation in tourism in the macro- and microeconomic levels.
\end{abstract}

Keywords: tourism, innovation, innovation in tourism, management.

\section{INTRODUCTION}

Innovation is considered as a major source of competitive advantage and economic growth (Porter and Ketels, 2003). Innovation is a set of scientific, technological, organizational, financial and commercial activities aimed at commercialization of existing knowledge, technologies and equipment. The result of innovation is new or additional product or service with newly developed qualities and features. There is a growing number of research and applications studied the phenomena of innovation where business mainly focuses on the process of manufacturing sector. The researchers study service sectors relative to manufacturing (Prajogo, 2006) and some have considered the difficulties in applying product development theories to services (Gallouj, 2002).

The innovation process is a process of creation, development, distribution and use of innovation. Also, the process of innovation in relation to the product can be defined as a process of successive transformation of ideas into goods through the stages of fundamental and applied research, engineering development, marketing, production.

Tourism is one of the major international activities and for many countries is an important source of income. Thus, the GDP of some countries almost entirely generated by tourist traffic. The importance of tourism for the world economy driven by the following feature. Tourism is a complex socioeconomic phenomenon which is not only economic activity but also a mean of inter-regional and international cultural exchange, a way to overcome different kinds of crises.

Obviously, there is an opportunity to understand innovation through this fast growing industry and define the categories of innovation.

\section{LITERATURE REVIEW}

\subsection{Understanding Innovation}

The term "innovation" in its modern sense has been introduced and applied by Joseph Schumpeter who was among the first to lay out a clear concept of entrepreneurship and who emphasized that the cyclical process is almost exclusively the result of innovation in the organization, both industrial and commercial. By innovation he means, the changes in the methods of production and transportation, production of a new product, change in the industrial organization, opening up of a new market. The 
innovation does not mean invention rather it refers to the commercial applications of new technology, new material, new methods and new sources of energy.

The main functions of innovation:

- Involvement of new productive forces in the process, enhancing productivity and production efficiency, reducing the costs;

- Increasing the level of life of every person and society as a whole due to the diversity and quality of products and services that meet the needs of the population;

- Helping to align the structure of production to the structure of the changing needs, contributing to the maintenance of a balance between supply and demand, between production and consumption.

Based on the Schumpeterian idea of "creative destruction", the Abernathy-Clark model tries to classify innovations in two dimensions: intensity of obsolescence of knowledge subsequent to an innovation, and intensity of changes in industrial linkages prompted by the innovations. The application to the tourism industry is attributable to Anne-Mette Hjalager (2002).

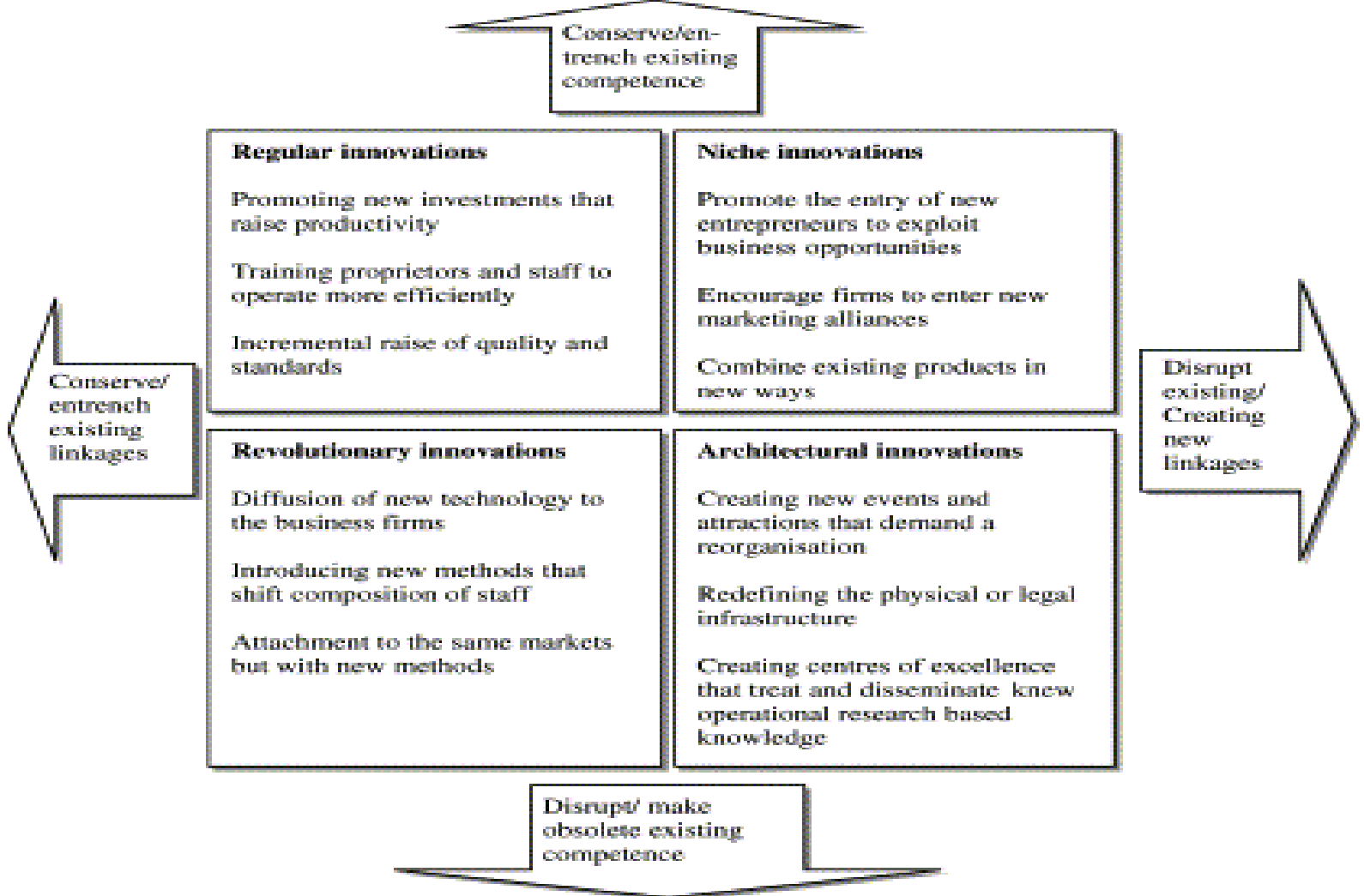

Source: Hjalager 2002, p. 467

\subsection{Tourism Through the Prism of Innovation Concept}

Tourist activity is not only the provision of services on the organization of travel but also a source of income of the state, many sectors of its economy. Tourism has a huge impact on such key economic sectors as transportation, services of hotels and restaurants, trade, construction, consumer goods and many other aspects, a driven catalyst for socio-economic development. Thus, the GDP of some countries almost entirely generated by tourist traffic. Tourism has a high "multiplicative" effect and is the "value of the coefficient indirect impact on tourism related industries". This indirect influence takes place through tourist's spending and respectively received income of tourism, transport, trade and other organizations. According to the World Tourism Organization, tourism has an indirect impact on the development of more than 32 branches of economy (UNWTO, 2016).

Tourism is one of the most profitable and fastest growing industries. According to the World Tourism Organization, by 2030 the number of international tourist arrivals will reach 1.8 billion. The largest share of international tourist arrivals will continue to occur in the European and Asia-Pacific region (Table. 1). 
Strategic Innovation in Tourism. A Conceptual and Review Approach

Table1. Outlook for International Tourist Arrivals

\begin{tabular}{|l|l|l|l|l|l|l|l|l|}
\hline Region & $\mathbf{2 0 0 8}$ & $\mathbf{2 0 0 9}$ & $\mathbf{2 0 1 0}$ & $\mathbf{2 0 1 1}$ & $\mathbf{2 0 1 2}$ & $\mathbf{2 0 1 3}$ & $\mathbf{2 0 1 4}$ & $\mathbf{2 0 1 5}$ \\
\hline World & 1.9 & -3.9 & 6.5 & 4.6 & 4.7 & 4.6 & 4.2 & 4.6 \\
\hline Europe & 0.3 & -3.9 & 3.1 & 6.4 & 3.9 & 4.8 & 2.3 & 4.7 \\
\hline Asia and Pacific & 1.1 & -1.6 & 13.2 & 6.2 & 7.1 & 6.9 & 5.7 & $\mathbf{5 . 6}$ \\
\hline Americas & 2.7 & -4.7 & 6.3 & 3.6 & 4.5 & 3 & 8.5 & $\mathbf{5 . 9}$ \\
\hline Africa & 2.9 & 4.5 & 9.3 & -0.7 & 4.6 & 4.4 & 1.1 & -3.3 \\
\hline Middle East & 20 & 5.4 & 13.1 & -9.6 & 2.2 & -2.9 & 6.7 & 1.7 \\
\hline
\end{tabular}

In terms of tourism expenditures, the leading positions are occupied by emerging economies such as China, Russia, Brazil. In the period 2000 - 2013 years, Chinese expenditure on outbound tourism increased nearly 10 times. China occupies a leading position in the world on this indicator, second and third place is occupied by the United States and Germany which indicated a moderate growth of tourism expenditures in 2013 at the level of 2-3\%.Developed countries such as Canada, United Kingdom, USA, Germany, and France indicated slower growth rate of tourism expenditure while Italy, Japan and Australia recorded a reduction of tourism expenditures (UNWTO, 2016).

Based on the above, it can be argued about the vital importance of the development of tourism for the entire world economy. Today's highly competitive, economic and political instability in many regions require constant tourism organizations adapt to rapidly changing environmental conditions. Constantly growing needs and demands of tourists, as well as the saturation of the tourist market pose tourism organizations need to continuously search for new types of tourism products, opening new directions, etc. Therefore, one can argue about the need to introduce innovative ways of development of the tourism industry.

In addition to the economic impact, innovation in the tourism sector also has social significance which can be viewed from two perspectives. On the one hand, innovation for individual tourism organizations contribute to the improvement of working conditions (organizational innovation), a full use of the intellectual and material resources (technological innovation), implementation of commercial potential (product innovation). On the other hand, in the tourism sector, innovations have a high public importance, namely contribute to overcoming the seasonality factor, sustainable tourism development, the improvement of employment and other.

According to the World Tourism Organization, one tourist creates 11 jobs on average which certainly indicates a high social importance of the tourism industry.

As a result, the recognition of the tourism industry is strategically important and priority that provides significant opportunities for the development of innovation activities in this area. After all, innovation is a factor in increasing competitiveness in all fields of management, including tourism.

\subsection{Innovation in Tourism Through Key Findings}

For the reason of classifying key findings, the database search has been performed as: Emerald, Sage Publications, and Science Direct. In total 20articles have been identified analyzing innovation in tourism.

\begin{tabular}{|l|l|l|}
\hline Author & Year & Factor Analysis \\
\hline Anne-Mette HJALAGER & 1997 & Innovation types. \\
\hline Anne-Mette HJALAGER & 2002 & Innovation types, innovation model for tourism. \\
\hline Cathy ENZ, Judy SIGUAW & 2003 & Innovation cases. \\
\hline Francina ORFILASINTES et al. & 2005 & Targeted market segment, seasonality, Performance. \\
\hline $\begin{array}{l}\text { Michael OTTENBACHER, Juergen } \\
\text { GNOTH }\end{array}$ & 2005 & Innovation success in hospitality industry. \\
\hline Jon SUNDBO et al. & 2007 & $\begin{array}{l}\text { Hotel size, organization, tourism firms' } \\
\text { innovativeness. }\end{array}$ \\
\hline $\begin{array}{l}\text { Michael } \\
\text { OTTENBACHER }\end{array}$ & 2007 & $\begin{array}{l}\text { Performance dimensions, new service performance } \\
\text { dimensions. }\end{array}$ \\
\hline $\begin{array}{l}\text { Ester MARTINEZROS, Francina } \\
\text { ORFILA-SINTES }\end{array}$ & 2009 & $\begin{array}{l}\text { Management, strategic decision of differentiation, market } \\
\text { orientation strategy. }\end{array}$ \\
\hline $\begin{array}{l}\text { Francina ORFILASINTES, Jan } \\
\text { MATTSSON }\end{array}$ & 2009 & $\begin{array}{l}\text { Service provider's competences (size, use of physical } \\
\text { capacity, additional services). }\end{array}$ \\
\hline Lori SIPE, Mark TESTA & 2009 & \begin{tabular}{l} 
Innovation and performance. \\
\hline
\end{tabular} \\
\hline
\end{tabular}




\begin{tabular}{|l|l|l|}
\hline \hline Bénédicte ALDEBERT et al. & 2011 & ICT and tourism innovation, tourism and event. \\
\hline Lopez FERNANDEZ et al. & 2011 & $\begin{array}{l}\text { Firm size, belonging to a business group, changes and } \\
\text { rigidities. }\end{array}$ \\
\hline XIANG Ying Mei et al. & 2012 & National Government's tourism innovation initiatives. \\
\hline Marta NAJDA-JANOSZKA & 2013 & Barriers to innovation in tourism industry \\
\hline XIANG Ying Mei et al. & 2015 & National government's roles. \\
\hline Vanda MARAKVA & 2015 & $\begin{array}{l}\text { Categories of innovation including, process, marketing, } \\
\text { institutional, management, product and service } \\
\text { innovations. }\end{array}$ \\
\hline Irma BOOYENS et al. & 2016 & $\begin{array}{l}\text { Conceptual strengthening, measurement and analysis of } \\
\text { innovation. }\end{array}$ \\
\hline
\end{tabular}

\section{DISCUSSION}

Innovation is a tool to achieve and apply results of scientific thought. From this point of view, tourism is extremely vast field for innovation as a complex cross-cutting socio-economic system. Tourism not only creates a new product or service, it also uses the innovations introduced in other areas of management. For example, hotels, travel agents, transport companies widely use the field of information technology development. Creating a tourist product, tourist services, booking of air - and train tickets - all these processes have reached a new level with the introduction of the latest developments in information technology.

The main factors influencing the innovative development of tourism include:

- the level of scientific and technological development, economic and political stability, availability of relevant legislative framework and other external factors;

- availability of the necessary volume of natural, financial and other resources;

- the level of development of tourist infrastructure;

- developed tourist market in the country and the degree and type of competition;

- availability of highly qualified personnel in all areas of tourism activities.

It should be noted that the most important factor influencing the innovation potential of the socioeconomic system is not only the availability of the necessary volume of all types of resources but also their quality, structure, balance and rationality of use. The improvement of these indicators can increase the resource potential without increasing the use of resources.

Main areas of innovation in the tourism sector can be extracted:

- introduction of new tourist routes, release of a new tourism or restaurant product, providing new hotel services;

- the use of new techniques and technologies;

- use of new tourist resources;

- application of new techniques and methods of organization of the business process;

- opening of new direction and new markets.

Innovative activity in any sector of economic management has its specific features and the tourist industry is no exception. This is due to the specifics of tourism services, supply and demand for them.

Considering the factors causing the specificity of the innovation process in the tourism sector, seven leading properties of the tourism product can be discussed:

1. Tourism services, as well as any other services are unable to storage. Therefore, managers of travel companies need to implement strictly tourist product in a timely manner that causes them to constantly look for new markets and new ways to promote tourism products.

2. The volume of sales of tourist services in the most areas is subject to seasonal fluctuations. In the off-season, additionally stimulated demand with additional proposals, pricing, diversification of offer has to be implemented. 
3. In the authors' opinion, considering the characteristics of tourist services it is necessary to refer not only to the subject of seasonal fluctuations but also political, economic, environmental and other external factors.

4. Services, including tourism are intangible. The consumer will be able to assess the quality of the product only after the receipt of services, therefore, an important factor influencing the decision to buy the consumer becomes the image and reputation of the tourist company.

5. Facts of sale and consumption of tourist services not coincide in time. Consumers buying tourist product in most cases for several days, weeks or months before the start of tourist services. Therefore, at the stage of sale, advertising printed products, the availability of reliable information on the complete vacation spot plays an important role.

6. For the consumer of tourist services, it is necessary to overcome a certain distance, to leave the place of permanent residence.

7. The consumers and producers of tourism services geographically separated in the tourist market, therefore the promotional activities covering a wide audience taking a particular relevance.

All of these features require a tourist services tourist service suppliers and travel agencies to constantly looking for new ways and means to attract consumers which lead to the innovative nature of tourism as a whole and the development of tourism which is inextricably linked with the constant involvement of various types of innovation.

The specific of innovation in the tourism sector is determined not only by the features of tourist services but also by characteristics of their consumers and producers.

As seen, the tourist activity is constantly looking for new ways and solutions and therefore innovations. For the implementation of innovative ideas and development it is necessary to form a flexible, adaptive multi-level governance system that would meet the current market requirements. At the level of the main tourist company, innovative management has to become a leading instrument for innovative processes. Quality control of the company largely impacts on organizational performance of the innovation activities, thus reducing the share of inefficient projects, as well as reducing the risks.

\section{CONCLuSION}

Innovation management in the tourism sector is a kind of cultural, economic and business activity to achieve the objectives of tourist companies on the basis of the effective organization of innovative processes. Innovation management includes various functions such as planning, marketing, organization, control, and others.

Monitoring and evaluation are among the basic functions of innovation management. The information obtained during the evaluation of the results of innovation is not only an indicator of efficiency but also the base for the development of the further strategy, operational and current planning. Since tourism is a cross-industry complex, the use of standard indicators of efficiency of innovative activity in the industry does not reflect the full ongoing innovation processes. Therefore, specific indicators should be used for the analysis and evaluation of innovation activities in the field of tourism. Along with innovation in methods of market research and information gathering, innovative ways to promote products and services of special importance among marketing innovations for tourist organizations are those that are associated with the improvement of the quality and safety of tourist services.

Innovations in the field of tourism sometimes occur quite suddenly and unpredictably, even under the influence of events in society. Therefore, the study of innovation processes, the reasons for the emergence of innovations, development of methods of their implementation is of great practical and scientific interest. The role of state is important in the development of innovations in the field of tourism and the development and implementation of the state support of these areas by relevant mechanisms.

\section{REFERENCES}

[1] Booyens, I. (2016). Tourism innovation in the global south: evidence from the Western Cape, South Africa. International Journal of Tourism Research, 12, 22-24. 
[2] Benedicte, A. (2011). Innovation in the tourism industry: The case of Tourism@. Tourism Management 32, 1204-1213.

[3] Enz, C. (2010). Cases of innovative practices in hospitality and related services - Set 4, Cornell Hospitality Report 10.

[4] Gallouj, F. (2002). Innovation in services and the attendant old and new myths. Journal of SocioEconomics, 31, 137-154.

[5] Hjalager, A. (1997). Innovation patterns in sustainable tourism - An analytical typology. Tourism Management 18, 35-41.

[6] Hjalager, A. (2002). Repairing innovation defectiveness in tourism. Tourism Management 23, 465-474.

[7] Lopez, F. (2011). Factors encouraging innovation in Spanish hospitality firms. Cornell Hospitality Quarterly 52, 144-152.

[8] Marta, N. (2014).Exploring barriers to innovation in tourism industry - the case of Southern region of Poland, Procedia - Social and Behavioral Sciences, 110, 190-201.

[9] Marakova, V. (2015). Innovation in tourism destinations. Extracted on October 2016 from http://www.wsb.edu.pl/container/FORUM\%20SCIENTIAE/ forum\%2 02016\%20nr\%201/ kwart alnik-1-2016-3.pdf

[10] Porter, M.E. and Ketels, C.H.M. (2003). Competitiveness: Moving to the next stage. Strategic Management Journal, 24, 415-431.

[11] Prajogo, D. (2006). The relationship between innovation and business performance - a comparative study between manufacturing and service firms. Journal of Knowledge and Process Management, 13, 218-225.

[12] Ottenbacher, M. (2007). Innovation management in the hospitality industry: different strategies for achieving success." Journal of Hospitality and Tourism Research 31, 431-454.

[13] Ottenbacher, M. (2005). How to develop successful hospitality innovation. Cornell Hotel and Restaurant Administration Quarterly 46, 205-222.

[14] Sundbo, J. (2007). The innovative behavior of tourism firms - comparative studies of Denmark and Spain." Research Policy, 88-106.

[15] Xiang, Y (2015). Innovation and collaboration: the role of the National Government in Norway, Tourism Analysis, 18, 519-531

[16] Verma, R. (2008). Key elements in service innovation: insights for the hospitality industry." Cornell Hospitality Roundtable Proceedings, 1-16.

[17] UN World Trade Organization, http://www2.unwto.org 